\title{
Secondary metabolites from Astragalus karjaginii BORISS and the evaluation of their effects on cytokine release and hemolysis
}

\author{
Behnaz Aslanipour $^{\mathrm{a}}$, Derya Gülcemal ${ }^{\mathrm{b}}$, Ayşe Nalbantsoy ${ }^{\mathrm{a}}$, Hasan Yusufoglu ${ }^{\mathrm{c}}$, Erdal Bedir ${ }^{\mathrm{d}, *}$ \\ a Department of Bioengineering, Faculty of Engineering, Ege University, Bornova, 35100 Izmir, Turkey \\ b Department of Chemistry, Faculty of Science, Ege University, Bornova, 35100 Izmir, Turkey \\ ${ }^{c}$ Department of Pharmacognosy, College of Pharmacy, Prince Sattam Bin Abdulaziz University, 11942 Al-Kharj, Saudi Arabia \\ d Department of Bioengineering, Faculty of Engineering, Izmir Institute of Technology, Urla, 35430 Izmir, Turkey
}

\section{A R T I C L E I N F O}

\section{Keywords:}

Astragalus karjaginii

Saponins

Cycloartane

Immune modulation

Cytokine stimulation

Hemolytic activity

\begin{abstract}
A B S T R A C T
A new cycloartane sapogenol and a new cycloartane xyloside were isolated from Astragalus karjaginii BORISS along with thirteen known compounds. The structures of the new compounds were established as 3-oxo$6 \alpha, 16 \beta, 24(S), 25$-tetrahydroxycycloartane (1) and 6-O- $\beta$-D-xylopyranosyl-3 $\beta, 6 \alpha, 16 \beta, 24(S), 25$-pentahydroxycycloartane (2) by 1D- and 2D-NMR experiments as well as ESIMS and HRMS analyses. The presence of the keto function at position 3 was reported for the first time for cyclocanthogenol sapogenin of Astragalus genus. In vitro immunomodulatory effects of the new compounds ( 1 and 2) along with the $n$ - $\mathrm{BuOH}$ and $\mathrm{MeOH}$ extracts of $A$. karjaginii at two different doses ( 3 and $6 \mu \mathrm{g}$ ) were tested on human whole blood for in vitro cytokine release (IL-2, IL-17A and IFN- $\gamma$ ) and hemolytic activities. The results confirmed that compound 2, a monodesmosidic saponin, had the strongest effect on the induction of both IL-2 $(6 \mu \mathrm{g}, 6345.41 \pm 0.12 \mathrm{pg} / \mathrm{mL}(\times 5), P<0.001)$ and a slight effect upon IL-17A $(3 \mu \mathrm{g}, 5217.85 \pm 0.72 \mathrm{pg} / \mathrm{mL}, P<0.05)$ cytokines compared to the other test compounds and positive controls (AST VII: Astragaloside VII; and QS-21: Quillaja saponin 21). All tested extracts and molecules also induced release of IFN- $\gamma$ remarkably ranging between $5031.95 \pm 0.05 \mathrm{pg} / \mathrm{mL}, P<0.001$ for $\mathrm{MeOH}$ extract $(6 \mu \mathrm{g})$ and $5877.08 \pm 0.06 \mathrm{pg} / \mathrm{mL}, P<0.001$ for compound 1 (6 $\mu \mathrm{g})$ compared to QS-21 $(6 \mu \mathrm{g}, 5924.87 \pm 0.1 \mathrm{pg} / \mathrm{mL}, P<0.001)$. Administration of AST VII and other test compounds did not cause any hemolytic activity, whereas QS-21 resulted a noteworthy hemolysis.
\end{abstract}

\section{Introduction}

Astragalus L., which is the largest genus in the family Leguminosae, is represented by 850 species, 527 of which are endemic, in the flora of Iran $[1,2]$. The isolation of a series of cycloartane and oleanane triterpenoids was reported from Astragalus species [3-13]. Their traditional and modern usages are primarily for immune-related complaints (frequent infections) or malignancies [14]. The crude Astragalus preparations are used for treating some illnesses such as leukemia, respiratory infections and diabetes in Iranian folk medicine [15].

Astragalus is generally considered as safe with few reported adverse events. Its extracts have been shown to enhance NK cells' activity leading to efficient elimination of tumor cells, together with stimulating the activity of other immune cells such as macrophages and B-cells [16-18]. A purified mixture containing mostly saponins (PMS) from Astragalus corniculatus against myeloid Graffi tumor in hamsters showed that the mixture could decrease the tumor transplantability, inhibit tumor growth in the early stages of tumor progression, reduce the percentage mortality and finally increase the mean survival time [19]. Kim and co-workers reported that the extract of Astragalus membranaceus suppressed the expression of Th2 cytokines and significantly decreased the TNF- $\alpha$ level. They also confirmed that the extract was effective for treatment of atopic dermatitis via regulating cytokines [20].

Among Astragalus constituents, mainly polysaccharides and cycloartane-type saponins were shown to be effective; the latter were more prominent to exhibit insecticidal, antifungal, cytotoxic, anthelmintic, immunostimulant and anti-inflammatory activities [1,21-24].

AST VII, a tridesmosidic glycoside from Astragalus species, was found to be the most active cycloartane during our screening studies to induce IL-2 production (\%139.6) [25]. Astragaloside I was the only effective compound on increasing not only NF- $\mathrm{kB}$-directed luciferase expression up to $65 \%$ but also the mRNA expression of inflammatory cytokines, such as IL-1 $\beta$ and TNF- $\alpha$ [14]. When adjuvant and hemolytic effects of IL-2 stimulating Astragalus saponins, namely AST VII and $\mathrm{MacB}$ (Macrophyllosaponin B) were evaluated in vitro and in vivo, the test compounds exhibited remarkable adjuvanicity with safe profiles

\footnotetext{
* Corresponding author.

E-mail address: erdalbedir@iyte.edu.tr (E. Bedir).
} 
warranting further studies to be tested in vaccine formulations [26].

In the present paper, as a continuation of our search on Astragalus genus to establish new bioactive compounds with immunostimulatory properties, A. karjaginii was studied that resulted in the isolation of two new cycloartane-type triterpenoids (1-2) along with thirteen known ones (3-15). The structure elucidation was completed by spectroscopic methods including $1 \mathrm{D}-\left({ }^{1} \mathrm{H},{ }^{13} \mathrm{C}\right)$, 2D-NMR (DQF-COSY, HSQC, and HMBC) and HRMS analyses. Additionally, the methanol and $n$-butanol extracts together with the new compounds (1 and 2) were tested for in vitro cytokine release (IL-2, IL-17A and IFN- $\gamma$ ) in activated whole blood cells by PMA plus ionomycin, as well as for their hemolytic activities in human erythrocyte cells.

\section{Results}

The molecular formula of $\mathbf{1}$ was determined as $\mathrm{C}_{30} \mathrm{H}_{50} \mathrm{O}_{5}$ by HRESIMS data $\left(m / z 513.3563[\mathrm{M}+\mathrm{Na}]^{+}\right.$, calcd 513.3560 for $\mathrm{C}_{30} \mathrm{H}_{50} \mathrm{O}_{5} \mathrm{Na}$ ), implying an unsaturation degree of 6 . The ${ }^{1} \mathrm{H}$ NMR spectrum of 1 showed resonances due to a cyclopropane methylene at $\delta$ 0.63 and 0.43 (each $1 \mathrm{H}, \mathrm{d}, J=4.0 \mathrm{~Hz}$ ), six tertiary methyl groups at $\delta$ $1.33(3 \mathrm{H}, \mathrm{s}), 1.20(6 \mathrm{H}, \mathrm{s}), 1.15(3 \mathrm{H}, \mathrm{s}), 1.14(3 \mathrm{H}, \mathrm{s})$ and $0.92(3 \mathrm{H}, \mathrm{s})$, and a secondary methyl group at $\delta 0.90(\mathrm{~d}, J=6.0 \mathrm{~Hz})$, suggesting a cycloartane-type triterpene nucleus (Fig. 1, Table 1). Additionally, three low-field proton resonances at $\delta 4.48$ (ddd, $J=8.0,8.0,5.0 \mathrm{~Hz}$ ), 3.56 (dd, $J=10.5,2.5 \mathrm{~Hz}$ ), and 3.51 (ddd, $J=9.0,9.0,4.5 \mathrm{~Hz}$ ) were observed, and their secondary alcoholic characters were confirmed by HSQC correlations.

In the low-field of ${ }^{13} \mathrm{C}$ NMR spectrum, in addition to oxymethine resonances, a tertiary alcohol carbon at $\delta 73.4$ and a carbonyl carbon at $\delta 217.4$ were also noticed (Table 2). The presence of a double bond as ketone group suggested that the skeleton had pentacyclic nature including the characteristic cyclopropane ring.

A detailed analysis of ${ }^{1} \mathrm{H}$ and ${ }^{13} \mathrm{C}$ NMR data, and comparison with those of cycloartane-type aglycones derived from Astragalus genus proposed that compound 1 was closely related with cyclocanthogenin [3 $3,6 \alpha, 16 \beta, 24(S)-25-p e n t a h y d r o x y c y c l o a r t a n e] ~[27]$ (Tables 1 and 2). Complete NMR assignments of $\mathbf{1}$ were accomplished by HSQC and COSY experiments, whereas to reveal the complete skeleton via connecting the partial structures, the HMBC spectrum was evaluated (Fig. 2).

It was evident from ${ }^{1} \mathrm{H}$ NMR spectrum that the oxymethine proton $\mathrm{H}-3$ of cyclocanthogenin $(\delta 3.20)$ was absent in compound $\mathbf{1}$, whereas, in the ${ }^{13} \mathrm{C}$ NMR spectrum, secondary alcohol of cyclocanthogenin's $\mathrm{C}-3$ $(\delta$ 79.6) was replaced with a ketone resonance $(\delta 217.4)$, inferring compound 1's structure as cyclocanthogenin-3-one. The HMBC correlations between the proton resonances at $\delta 1.33$ and 1.20 assigned for Me-28 and Me-29, respectively, with the carbon resonance at $\delta 217.4$
Table 1

${ }^{1} \mathrm{H}$ NMR data $(\mathrm{J}$ in $\mathrm{Hz})$ of compounds 1,2 and $2 \mathrm{a}\left(500 \mathrm{Mz}, \delta \mathrm{ppm}\right.$, in $\mathrm{CDCl}_{3}, \mathrm{CD}_{3} \mathrm{OD}$ and $\mathrm{CDCl}_{3}$, respectively).

\begin{tabular}{|c|c|c|c|}
\hline $\mathrm{H}$ & $\begin{array}{l}1 \\
\delta_{\mathrm{H}}(J \text { in } \mathrm{Hz})\end{array}$ & $\begin{array}{l}2 \\
\delta_{\mathrm{H}}(J \text { in } \mathrm{Hz})\end{array}$ & $\begin{array}{l}2 \mathrm{a} \\
\delta_{\mathrm{H}}(J \text { in } \mathrm{Hz})\end{array}$ \\
\hline 1 & $2.06,1.36, \mathrm{~m}$ & $1.56,1.28, \mathrm{~m}$ & $1.21,1.60, \mathrm{~m}$ \\
\hline 2 & $2.61,2.42, \mathrm{~m}$ & $1.91,1.87, \mathrm{~m}$ & $1.78,1.55, \mathrm{~m}$ \\
\hline 3 & - & 3.20 , dd $(11.2,4.0)$ & 4.50 , dd $(11.0,4.5)$ \\
\hline 4 & - & - & - \\
\hline 5 & $1.92, \mathrm{~d}(9.0)$ & $1.58, \mathrm{~d}(9.5)$ & $1.63, \mathrm{~d}(9.2)$ \\
\hline 6 & $\begin{array}{l}3.51, \text { ddd }(9.0 \text {, } \\
9.0,4.5)\end{array}$ & $\begin{array}{l}\text { 3.52, ddd }(9.5,9.5 \text {, } \\
4.5)\end{array}$ & $3.38, \operatorname{td}(8.8,3.8)$ \\
\hline 7 & $1.40, \mathrm{~m}$ & $1.77,1.62, \mathrm{~m}$ & $1.48,1.70, \mathrm{~m}$ \\
\hline 8 & $\begin{array}{l}1.76 \text {, dd (12.0, } \\
4.0)\end{array}$ & 1.87, dd $(12.0,4.2)$ & 1.75 , dd $(10.8,4.7)$ \\
\hline 9 & - & - & - \\
\hline 10 & - & - & - \\
\hline 11 & $1.56,1.40, \mathrm{~m}$ & $1.84,1.42, \mathrm{~m}$ & $1.84,1.42, \mathrm{~m}$ \\
\hline 12 & $1.65, \mathrm{~m}$ & $1.62, \mathrm{~m}$ & $1.61, \mathrm{~m}$ \\
\hline 13 & - & - & - \\
\hline 14 & - & - & - \\
\hline \multirow[t]{2}{*}{15} & $\begin{array}{l}2.02, \text { dd }(12.0 \text {, } \\
8.0)\end{array}$ & 2.05 , dd $(12.7,8.0)$ & $1.22, \mathrm{~m}$ \\
\hline & $\begin{array}{l}1.35 \text {, dd (12.0, } \\
5.0)\end{array}$ & 1.37, dd $(12.7,5.2)$ & 2.17 , dd $(13.7,8.3)$ \\
\hline 16 & $\begin{array}{l}4.48, \text { ddd }(8.0, \\
8.0,5.0)\end{array}$ & $\begin{array}{l}4.43 \text {, ddd }(8.0,8.0 \text {, } \\
5.2)\end{array}$ & 5.25 , ddd $(6.1,7.5,7.5)$ \\
\hline 17 & $\begin{array}{l}1.63, \text { dd }(9.5 \text {, } \\
8.2)\end{array}$ & $1.69, \mathrm{dd}(9.9,8.0)$ & $1.85, \mathrm{~m}$ \\
\hline 18 & $1.15, \mathrm{~s}$ & $1.14, \mathrm{~s}$ & $1.10, \mathrm{~s}$ \\
\hline \multirow[t]{2}{*}{19} & $0.63, \mathrm{~d}(4.0)$ & $0.56, \mathrm{~d}(4.2)$ & $0.30, \mathrm{~d}(4.5), 0.49, \mathrm{~d}(4.4)$ \\
\hline & $0.43, \mathrm{~d}(4.0)$ & $0.23, \mathrm{~d}(4.2)$ & \\
\hline 20 & $1.91, \mathrm{~m}$ & $1.90, \mathrm{~m}$ & $1.83, \mathrm{~m}$ \\
\hline 21 & $0.90, \mathrm{~d}(6.0)$ & $0.94, \mathrm{~d}(6.5)$ & $0.91, \mathrm{~d}(5.8)$ \\
\hline 22 & $1.84,1.07, \mathrm{~m}$ & $1.80,1.24, \mathrm{~m}$ & $1.01,1.28, \mathrm{~m}$ \\
\hline 23 & $2.04,1.03, \mathrm{~m}$ & $1.65,1.45, \mathrm{~m}$ & $1.52,1.60, \mathrm{~m}$ \\
\hline 24 & $\begin{array}{l}3.56 \text {, dd }(10.5 \text {, } \\
2.5)\end{array}$ & 3.38 , dd $(10.5,2.4)$ & 4.68, dd $(9.6,2.2)$ \\
\hline 25 & - & - & - \\
\hline 26 & $1.20, \mathrm{~s}$ & $1.15, \mathrm{~s}$ & $1.18, \mathrm{~s}$ \\
\hline 27 & $1.14, \mathrm{~s}$ & $1.16, \mathrm{~s}$ & $1.18, \mathrm{~s}$ \\
\hline 28 & $1.33, \mathrm{~s}$ & $1.18, \mathrm{~s}$ & $0.91, \mathrm{~s}$ \\
\hline 29 & $1.20, \mathrm{~s}$ & $0.92, \mathrm{~s}$ & $0.97, \mathrm{~s}$ \\
\hline 30 & $0.92, \mathrm{~s}$ & $0.98, \mathrm{~s}$ & $0.93, \mathrm{~s}$ \\
\hline $1^{\prime}$ & & $4.29, \mathrm{~d}(7.5)$ & $4.57, \mathrm{~d}(6.6)$ \\
\hline $2^{\prime}$ & & 3.17 , dd $(7.5,9.0)$ & 4.87, dd $(8.5,6.7)$ \\
\hline $3^{\prime}$ & & $3.28, \mathrm{t}(9.0)$ & $5.11, \mathrm{t}(8.5)$ \\
\hline $4^{\prime}$ & & $3.45, \mathrm{~m}$ & $4.93, \operatorname{td}(8.3,5.2)$ \\
\hline $5^{\prime}$ & & $\begin{array}{l}3.82 \text {, dd }(5.2,11.4) \text {, } \\
3.16 \text {, t (11.4) }\end{array}$ & $\begin{array}{l}4.10 \text {, dd }(11.9,5.0), 3.32 \text {, } \\
\text { dd }(11.9,8.4)\end{array}$ \\
\hline $\mathrm{COC}_{3}$ & & & $\begin{array}{l}1.99(\times 2), 2.01,2.03 \\
2.04,2.10\end{array}$ \\
\hline
\end{tabular}

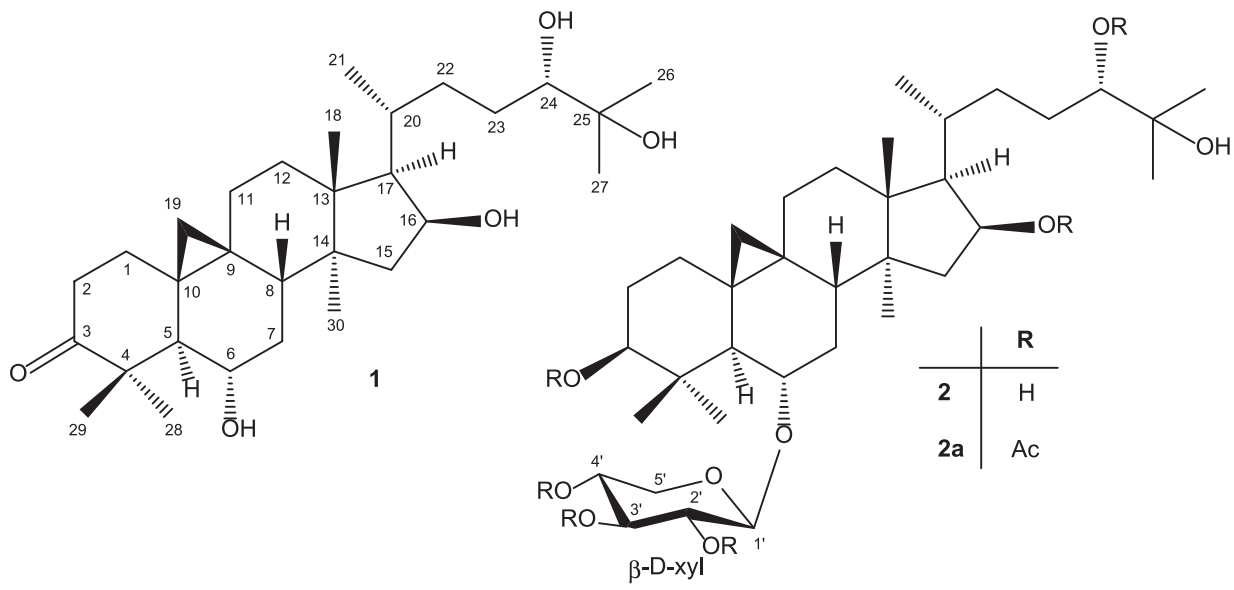

Fig. 1. Structures of compounds 1,2 and $2 a$. 
Table 2

${ }^{13} \mathrm{C}$ NMR data of compounds 1,2 and $2 \mathrm{a}^{\mathrm{a}}\left(125 \mathrm{MHz}, \delta \mathrm{ppm}\right.$, in $\mathrm{CDCl}_{3}, \mathrm{CD}_{3} \mathrm{OD}$ and $\mathrm{CDCl}_{3}$, respectively).

\begin{tabular}{|c|c|c|c|}
\hline $\mathrm{C}$ & $\begin{array}{l}\mathbf{1} \\
\delta_{\mathrm{C}}\end{array}$ & $\begin{array}{l}2 \\
\delta_{\mathrm{C}}\end{array}$ & $\begin{array}{l}\mathbf{2 a} \\
\delta_{\mathrm{C}}\end{array}$ \\
\hline 1 & 31.9 & 33.4 & 31.4 \\
\hline 2 & 35.8 & 29.9 & 26.6 \\
\hline 3 & 217.4 & 79.6 & 80.2 \\
\hline 4 & 50.4 & 42.7 & 40.2 \\
\hline 5 & 53.8 & 52.8 & 51.5 \\
\hline 6 & 69.9 & 79.6 & 79.1 \\
\hline 7 & 37.8 & 34.0 & 33.9 \\
\hline 8 & 48.1 & 46.3 & 45.8 \\
\hline 9 & 21.5 & 22.0 & 21.0 \\
\hline 10 & 28.2 & 29.0 & 28.6 \\
\hline 11 & 26.3 & 26.6 & 26.0 \\
\hline 12 & 32.6 & 34.0 & 32.3 \\
\hline 13 & 45.5 & 46.2 & 46.9 \\
\hline 14 & 46.6 & 46.6 & 45.4 \\
\hline 15 & 47.9 & 47.9 & 45.4 \\
\hline 16 & 72.8 & 73.4 & 75.6 \\
\hline 17 & 57.1 & 58.0 & 54.1 \\
\hline 18 & 19.3 & 18.1 & 19.9 \\
\hline 19 & 31.2 & 28.4 & 29.1 \\
\hline 20 & 26.6 & 29.0 & 30.4 \\
\hline 21 & 17.8 & 18.4 & 18.2 \\
\hline 22 & 31.4 & 33.8 & 32.5 \\
\hline 23 & 26.1 & 28.6 & 26.6 \\
\hline 24 & 75.4 & 78.4 & 80.5 \\
\hline 25 & 73.4 & 74.0 & 72.6 \\
\hline 26 & 27.2 & 25.3 & 25.3 \\
\hline 27 & 23.2 & 25.4 & 26.8 \\
\hline 28 & 28.4 & 28.4 & 27.7 \\
\hline 29 & 20.3 & 15.8 & 16.7 \\
\hline 30 & 20.4 & 19.8 & 19.7 \\
\hline $1^{\prime}$ & & 105.4 & 101.1 \\
\hline $2^{\prime}$ & & 75.5 & 71.5 \\
\hline $3^{\prime}$ & & 78.1 & 71.9 \\
\hline $4^{\prime}$ & & 71.3 & 79.1 \\
\hline $5^{\prime}$ & & 66.6 & 62.1 \\
\hline
\end{tabular}

${ }^{\text {a }} \mathrm{COCH}_{3}: 20.88$ (× 2), 21.14, 21.14, 21.39, 21.44; $\underline{\mathrm{COCH}}_{3}: 169.5,169.9,170.4,171.0$, $171.4,172.4$

allowed us to facilitate the keto group at C-3 (Fig. 2). Additionally, the relative configurations of the oxygenated atoms were determined by the magnitude of the vicinal proton-proton coupling constants to be $\alpha-\mathrm{OH}$ for C-6 ( $\delta 3.51$, ddd, $\left.J=9.0,9.0,4.5 \mathrm{~Hz}, \mathrm{H}_{\mathrm{ax}}-6\right)$ and $\beta-\mathrm{OH}$ for $\mathrm{C}-16$ $\left(\delta 4.48\right.$, ddd, $\left.J=8.0,8.0,5.0 \mathrm{~Hz}, \mathrm{H}_{\mathrm{ax}}-16\right) .{ }^{1} \mathrm{H}$ and ${ }^{13} \mathrm{C}$ NMR data for $\mathrm{H}-24$ and $\mathrm{C}-24$ are comparable to those reported for analogous compounds having a $24 S$ configuration $[9,11,12]$. Thus, the structure of 1 was elucidated as $6 \alpha, 16 \beta, 24(S), 25$-tetrahydroxycycloartane-3-one.

The HRESIMS spectrum of $2\left(\mathrm{~m} / z 647.4147[\mathrm{M}+\mathrm{Na}]^{+}\right.$, calcd for $\mathrm{C}_{35} \mathrm{H}_{60} \mathrm{O}_{9} \mathrm{Na}, 647.4145$ ) supported a molecular formula of $\mathrm{C}_{35} \mathrm{H}_{60} \mathrm{O}_{9} \mathrm{Na}$. The ${ }^{1} \mathrm{H}$ NMR spectrum of $\mathbf{2}$ showed resonances due to a cyclopropane methylene at $\delta 0.56$ and 0.23 (each $1 \mathrm{H}, \mathrm{d}, J=4.2 \mathrm{~Hz}$ ), six tertiary methyl groups at $\delta 1.18(3 \mathrm{H}, \mathrm{s}), 1.16(3 \mathrm{H}, \mathrm{s}), 1.15(3 \mathrm{H}, \mathrm{s}), 1.14(3 \mathrm{H}, \mathrm{s})$, $0.98(3 \mathrm{H}, \mathrm{s})$ and $0.92(3 \mathrm{H}, \mathrm{s})$, a secondary methyl group at $\delta 0.94(\mathrm{~d}$, $J=6.5 \mathrm{~Hz}$ ), and four methine proton resonances at $\delta 4.43$ (ddd, $J=8.0,8.0,5.2 \mathrm{~Hz}$ ), 3.52 (ddd, $J=9.5,9.5,4.5 \mathrm{~Hz}$ ), 3.38 (dd, $J=10.5,2.4 \mathrm{~Hz})$ and $3.20(\mathrm{dd}, J=11.2,4.0 \mathrm{~Hz})$, which were indicative of secondary alcoholic functions (Fig. 1, Table 1). On the other hand, the relative configurations of the oxygenated atoms were determined by the magnitude of the vicinal proton-proton coupling constants to be: $\mathrm{C}-3\left(\beta-\mathrm{OH} ; \delta 3.20\right.$, dd, $\left.J=11.2,4.0 \mathrm{~Hz} . \mathrm{H}_{\mathrm{ax}}-3\right), \mathrm{C}-6$ $\left(\alpha-\mathrm{OH} ; \delta 3.52\right.$, ddd, $\left.J=9.5,9.5,4.5 \mathrm{~Hz}, \mathrm{H}_{\mathrm{ax}}-6\right)$ and $\mathrm{C}-16(\beta-\mathrm{OH} ; \delta$ 4.43, ddd, $\left.J=8.0,8.0,5.2 \mathrm{~Hz}, \mathrm{H}_{\mathrm{ax}}-16\right) .{ }^{1} \mathrm{H}$ and ${ }^{13} \mathrm{C}$ NMR data for $\mathrm{H}-24$ and $\mathrm{C}-24$ are comparable to those reported for analogous compounds having a $24 S$ configuration $[9,11,12]$. The NMR data of the aglycone moiety of $\mathbf{2}$ were in good agreement with those reported for cyclocanthogenin [3] with glycosylation shift for C-6 ( $\delta$ 79.6) (Table 2). The ${ }^{1} \mathrm{H}$ NMR spectrum of 2 displayed only one anomeric proton resonance at $\delta 4.29$ (d, $J=7.5 \mathrm{~Hz}$ ) in the sugar region verifying a monosaccharidic sapogenol. Full assignments of the proton and carbon resonances of $\mathbf{2}$ were secured by COSY and HMQC spectra. On the basis of proton and carbon data and comparison with those of previously identified cyclortane glycosides from Astragalus genus, the sugar unit was readily identified as $\beta$-xylopyranosyl unit.

As explained in the experimental part, compound 2 was first isolated in its acetylated form due to separation difficulties. Acetylated form of $\mathbf{2}$ yielded a hexaacetate, 2a. The IR spectrum of $\mathbf{2 a}$ still exhibited a free $\mathrm{OH}$ absorption band after acetylation $\left(3450 \mathrm{~cm}^{-1}\right)$, indicating the presence of a free hydroxyl group on 2 . The acetylation pattern of the sugar residue $\left(C-2_{x y l}, C-3_{x y l}\right.$ and $C-4$ xyl $)$ was readily deduced from the COSY spectrum of $\mathbf{2 a}$, which showed significant downfield shifts for $\mathrm{H}-2_{\mathrm{xyl}}, \mathrm{H}-3_{\mathrm{xyl}}$ and $\mathrm{H}-4_{\mathrm{xyl}}$ resonances ranging between 1.5 and $1.9 \mathrm{ppm}$ (see Table 1). The remaining 3 acetoxyl resonances deriving from the sapogenol moiety also implied a nonacetylated $\mathrm{OH}$ group. Indeed, the resonances due to $\mathrm{H}-3, \mathrm{H}-16$ and $\mathrm{H}-24$ were observed at $\delta 4.50,5.25$ and 4.68, respectively, exhibiting the expected downfield shift in comparison to 2 ( $\delta 3.20,4.43$ and 3.38, respectively). No downfield shifts were observed for H-6, supporting the site of glycosidation. These results clarified the site of the nonacetylated hydroxyl group on the sapogenol moiety as C-25 with tertiary alcohol character. Full NMR assignments of 2a were also secured by COSY and HSQC. In order to establish the interfragment relationship, HMBC was performed, which not only connected the fragments but also proved xylose residue's position (Fig. 2). Thus, the ${ }^{3} J_{\mathrm{C}-\mathrm{H}}$ longdistance correlation between the proton resonance at $\delta 4.57\left(\mathrm{H}-1_{\mathrm{xyl}}\right)$ and the carbon resonance at $\delta 79.1(\mathrm{C}-6)$ allowed us to determine the linkage site.

The acid hydrolysis of $\mathbf{2}$ afforded D-xylose (confirmed by the optical rotation data of isolated sugar). Thus, compound $\mathbf{2}$ was elucidated as 6 $O$ - $\beta$-D-xylopyranosyl-3 $\beta, 6 \alpha, 16 \beta, 24(S), 25$-pentahydroxycycloartane.
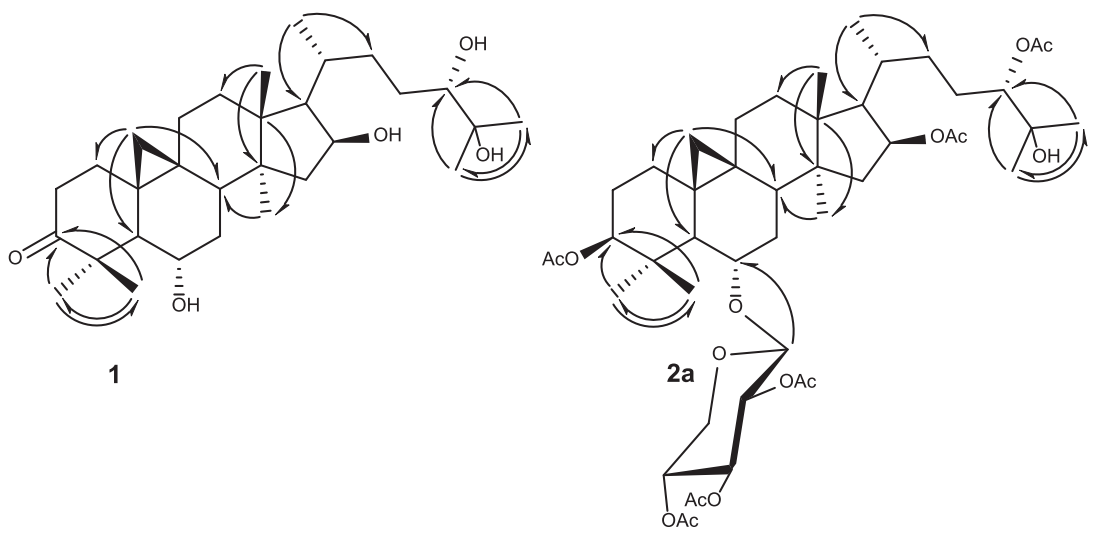

Fig. 2. Key long-range correlations [HMBCs (H to $\mathrm{C})]$ of $\mathbf{1}$ and $\mathbf{2 a}$. 
Additionally, cycloastragenol (3) [4], cyclocanthoside E (4) [28], astragaloside IV (5) [29], astragaloside VIII (6) [30], cycloascauloside B (7) [31], cyclocephaloside I (8) [3], astrachrysoside A (9) [32], 3-O-[aL-rhamnopyranosyl-( $1 \rightarrow 2)$ - $\alpha$-L-arabinopyranosyl- $(1 \rightarrow 2)-\beta$-D-xylopyranosyl]-6-O- $\beta$-D-glucopyranosyl-3 $\beta, 6 \alpha, 16 \beta, 24(S), 25$-pentahydroxycycloartane (10) [9], 3-O-[ $\alpha$-L-rhamnopyranosyl- $(1 \rightarrow 2)-\alpha$-L-arabinopyranosyl-( $1 \rightarrow 2)$ - $\beta$-D-xylopyranosyl]-6-O- $\beta$-D-glucopyranosyl$3 \beta, 6 \alpha, 16 \beta, 24 \alpha$-tetrahydroxy-20(R), 25-epoxycycloartane (11) [9], 3-O[ $\alpha$-L-arabinopyranosyl-( $1 \rightarrow 2)-\beta$-D-xylopyranosyl]-6-O- $\beta$-D-glucopyranosyl-3 $\beta, 6 \alpha, 16 \beta, 24 \alpha$-tetrahydroxy-20(R),25-epoxycycloartane (12) [9], cyclocephalosoide I (13) [16], 6-O- $\beta$-D-glucopyranosyl$3 \beta, 6 \alpha, 16 \beta, 24 \alpha$-tetrahydroxy-20(R),25-epoxycycloartane (14) [33] and cyclocanthoside A (15) [34] were also isolated from Astragalus karjaginii, and identified based on comparison of their spectroscopic data with literature values.

In this study, the analyses of IL-2, IFN- $\gamma$ and IL-17A cytokine release in stimulated whole blood using PMA plus ionomycin were determined by ELISA. Two compounds, viz. QS-21 and AST VII, were used as positive controls.

Compared to whole blood control group induced by PMA plus ionomicin $(6273.41 \pm 0.21 \mathrm{pg} / \mathrm{mL}, \times 5)$, the results showed that the compounds ( 1 and 2 ) besides the $\mathrm{n}-\mathrm{BuOH}$ and $\mathrm{MeOH}$ extracts enhanced the secretion of $\mathrm{IL}-2$ considerably in both test doses ( 3 and $6 \mu \mathrm{g}$ ) (Fig. 3). It is obvious that the presence of sugar unit results a slight variation for IL-2 secretion. For instance, for both 3 and $6 \mu$ g doses, monosaccharidic $2(7266.16 \pm 0.170 .09 \mathrm{pg} / \mathrm{mL},(\times 5), P<0.001$ and $6985.18 \pm 0.04 \mathrm{pg} / \mathrm{mL},(\times 5), P<0.001)$ was more effective than compound 1 for IL-2 release [(6261.71 $\pm 0.09 \mathrm{pg} / \mathrm{mL},(\times 5)$, $P<0.001$ and $6345.41 \pm 0.12 \mathrm{pg} / \mathrm{mL},(\times 5), P<0.001)$, respectively]. On the other hand, the positive controls QS-21 $(6 \mu \mathrm{g}$, $7219.51 \pm 0.09 \mathrm{pg} / \mathrm{mL},(\times 5), \quad P<0.001)$ and AST VII $(6 \mu \mathrm{g}$, $6560.84 \pm 0.29 \mathrm{pg} / \mathrm{mL},(\times 5), P<0.001)$ were also active but not as much as compound 2 's lower dose of $3 \mu \mathrm{g}$.

In the case of IL-17A secretion, except compound 2 ( $3 \mu \mathrm{g}$, $5217.85 \pm 0.72 \mathrm{pg} / \mathrm{mL}, P<0.05)$ which showed slight induction upon IL-17A cytokine comparing to PMA + Iyonomycin (4883.42 $\pm 0.072,(\times 5), \mathrm{pg} / \mathrm{mL})$, none of the compounds showed any effect.

QS-21 was found to be the most active compound towards induction of IFN- $\gamma$ release $(6 \mu \mathrm{g}, 5924.87 \pm 0.1 \mathrm{pg} / \mathrm{mL}, P<0.001)$, whereas all the test compounds and extracts had also notable effects. Among them, compound 1 showed the most prominent effect on IFN- $\gamma$ production at $6 \mu \mathrm{g}(5877.08 \pm 0.06 \mathrm{pg} / \mathrm{mL}, P<0.001)$ compared to whole blood
Table 3

Hemolytic activities of $n$-butanolic, methanolic extracts, and compounds 1 and 2. , b,c $^{\text {, }}$

\begin{tabular}{lll}
\hline Group $(\mu \mathrm{g} / \mathrm{mL})$ & Absorbance value & Hemolytic percentage (\%) \\
\hline Saline & $0.140 \pm 0.004$ & $0.00 \pm 0.60$ \\
Distillated water & $1.024 \pm 0.04$ & $100.00 \pm 5.88^{* * *}$ \\
QS-21500 & $1.112 \pm 0.044$ & $87.19 \pm 5.52^{* * *}$ \\
QS-21250 & $0.767 \pm 0.008$ & $60.04 \pm 1.07^{* * *}$ \\
QS-21125 & $0.710 \pm 0.009$ & $55.26 \pm 1.17^{* * *}$ \\
QS-21 50 & $0662 \pm 0.0002$ & $50.25 \pm 1.11^{* * *}$ \\
AST VII 500 & $0.145 \pm 0.001$ & $-1.51 \pm 0.33$ \\
AST VII 250 & $0.112 \pm 0.003$ & $-2.08 \pm 0.16$ \\
AST VII 125 & $0.103 \pm 0.003$ & $-2.39 \pm 0.14$ \\
AST VII 50 & $0.100 \pm 0.006$ & $-4.47 \pm 0.54$ \\
Compound 1500 & $0.131 \pm 0.005$ & $-2.91 \pm 0.69$ \\
Compound 1250 & $0.119 \pm 0.001$ & $-4.09 \pm 0.15$ \\
Compound 1125 & $0.097 \pm 0.002$ & $-6.40 \pm 0.26$ \\
Compound 1 50 & $0.078 \pm 0.001$ & $-8.33 \pm 0.17$ \\
Compound 2500 & $0.157 \pm 0.001$ & $-0.30 \pm 0.20$ \\
Compound 2250 & $0.141 \pm 0.001$ & $-1.89 \pm 0.15$ \\
Compound 2125 & $0.096 \pm 0.002$ & $-6.46 \pm 0.25$ \\
Compound 2 50 & $0.082 \pm 0.001$ & $-8.05 \pm 0.20$ \\
Butanol extract 500 & $0.188 \pm 0.002$ & $2.87 \pm 0.31$ \\
Butanol extract 250 & $0.146 \pm 0.002$ & $-1.35 \pm 0.32$ \\
Butanol extract 125 & $0.097 \pm 0.001$ & $-6.33 \pm 0.15$ \\
Butanol extract 50 & $0.188 \pm 0.002$ & $-7.24 \pm 0.25$ \\
MeOH extract 500 & $0.185 \pm 0.002$ & $2.60 \pm 0.29$ \\
MeOH extract 250 & $0.142 \pm 0.002$ & $-1.76 \pm 0.25$ \\
MeOH extract 125 & $0.094 \pm 0.008$ & $-6.70 \pm 0.10$ \\
MeOH extract 50 & $0.085 \pm 0.008$ & $-7.617 \pm 0.10$ \\
& & \\
\hline
\end{tabular}

a $* p<0.05 ; * * p<0.01 ; * * p<0.001$.

${ }^{\mathrm{b}}$ Hemolytic percents of saline and distilled water were included as minimal and maximal hemolytic control.

${ }^{\mathrm{c}}$ All values represent the mean \pm standard deviation (n $1 / 43$ test).

control group induced by PMA plus ionomicin $(4883.42 \pm 0.071 \mathrm{pg} /$ $\mathrm{mL}, P>0.05)$.

A. karjaginii extracts and the new compounds were also investigated for their hemolytic activities. As it is shown in Table 3, QS-21 caused strong hemolysis at all test concentrations $(500,250,125,50 \mu \mathrm{g} / \mathrm{mL}$, $P<0.001$ ), whereas the Astragalus compounds (1, 2 and AST VII) and extracts exhibited no hemolytic effect.

\section{Discussion}

Cytokines with peptide-based structures have crucial roles in the human immune system, such as inflammatory response, autoimmunity,

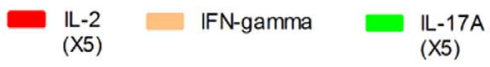

Fig. 3. Immunomodulatory activities of the $n$-butanol and methanol extracts of $A$. karjaginii, and compounds 1 and 2.

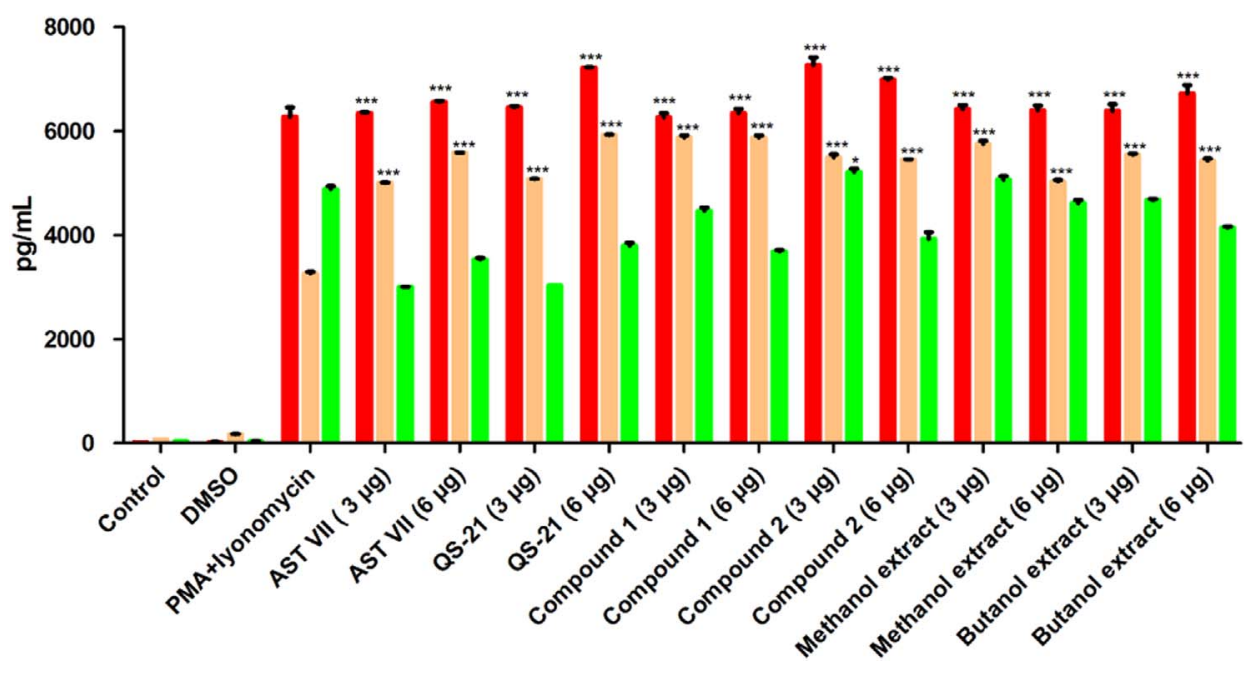


normal T-cell-mediated immunity, cancer and allergy [35-38]. The immune response is categorized in two groups based on the cytokine profile induced: Th1 or Th2. The Th1 profile is described by the initial production of IFN- $\gamma$ and IL-12 with an effector phase of T lymphocytes producing IL-2 and IFN- $\gamma$ and mediating cytotoxic activity (CTL). In contrast, Th2 responses are put forth by IL- 4 with predominantly IL- 5 and IL-10 producing $\mathrm{T}$ cells in the active phase driving antibody production $[19,21,23,39-41]$. IL-17A is the principal member of the family named IL-17A cytokine group [42]. The essential roles of this family are induction and facilitation of pro-inflammatory responses [43]. IL-17A inhibitors are under investigation to treat autoimmune diseases like rheumatoid arthritis, psoriasis and inflammatory bowel disease. The role of IL-17A for Th17 cells in vitiligo pathogenesis was also confirmed [44]. Concisely, IL-2, IFN- $\gamma$ and IL-17A are major cytokines with different functions for the immune system, and developing new molecules modulating them will have a potential use in therapy. Additionally, based on the earlier studies, one might advise that the specific molecules turning on the cytokine gene expression is more beneficial than injectable cytokines possessing too low therapeutic index [45-48].

Astragalus preparations have been shown to stimulate immune system on cellular and humoral level. Earlier studies undeniably pointed to induction of cytokines such as interleukins and interferons for their immunostimulatory actions $[26,49,50]$. The purified components of crude Astragalus preparations such as polysaccharides and saponins were found to be major contributors of the immunomodulatory actions [14,50,51]. Thus, Astragalus species and their constituents deserve detailed investigation for their immunomodulatory properties.

In one of our previous reports, Astragalus extracts and their cycloartane-type saponins were screened for their immunomodulatory properties via measuring cytokine levels (IL- $1 \beta$, IL- 8 and TNF- $\alpha$, IL-2, IL-4 and IFN- $\gamma$ ), which revealed noteworthy effects on IL-2 induction [25]. In the same study, the crude saponin extract of Astragalus oleifolius, rich in acyclic side-chain bidesmosidic saponins, was found to be the most active fraction with $141.2 \% \mathrm{IL}-2$ induction at $3 \mu \mathrm{g} / \mathrm{mL}$. In contrast, purified glycosides of 20,24-epoxy and 20,25-epoxy side-chain cycloartanes showed higher IL-2 inducing activity than those of acycliccycloartane derivatives as well as the aglycone of 20,24-epoxy cycloartanes, cycloastragenol. In a continuation of this study, one of the major components of A. oleifolius, namely Mac B, were shown to be a potent adjuvant in vivo via increasing BSA-specific IgG, IgG1 and IgG2b antibody titers, and IFN- $\gamma$ level at $90 \mu \mathrm{g}$ dose, inferring potential of acyclic side-chain cyloartane glycosides.

Compared to the results of Yesilada et al. and Nalbantsoy et al., this study made the structure-activity relationship more complicated for cycloartane chemistry $[25,26]$. Firstly, the monoglycosidic compound 2 with acyclic side chain exhibited stronger or equal potency on IL-2 and IFN- $\gamma$ induction compared to the positive controls, QS-21 and tridesmosidic AST VII. This suggested that the number of sugar units extending from aglycone is not as significant as it thought to be for cycloartane chemistry. Secondly, the $\mathrm{C}-3$ oxidized form of cyclocanthogenol (1), sapogenin of compound 2, also provided significant effects on the release of the same cytokines. Based on this data, one might hypothesize that the sapogenin framework with acyclic sidechain is more important than the sugar content on the structure. These findings contradict the results of earlier studies dealing with saponin structure-immunostimulatory activity relationships, which mostly emphasized the presence of long-chain branched/unbranched sugar units extending from $\mathrm{C}-3$ and $\mathrm{C}-28$ positons, acylation on the saccharidic parts, and an aldehyde function on the aglycone for higher activity [52-54].

On the other hand, except compound 2 at the dose of $3 \mu \mathrm{g}$ with a slight effect, none of the tested compounds showed notable effect on IL17A secretion. As IL-17A is a key pro-inflammatory cytokine, the patients with autoimmune diseases must approach to formulations of Astragalus precariously.

Saponins are well-known for their hemolytic effects. The overriding basis of hemolysis has been determined to be cell membrane swelling due to pore formation, partial entry of extracellular $\mathrm{Ca}^{2+}$ and ceramide formation [55-57]. In this study, the extracts of A. karjaginii and the new compounds were also evaluated for their hemolytic activities, which showed no hemolysis on erythrocytes. On the other hand, the only saponin-type adjuvant QS-21, which is in clinical trials as part of human vaccine formulations, displayed high hemolytic activity, whereas the other positive control AST VII caused no hemolysis.

Based on the safer profile mentioned above, we believe that the cycloartane-saponins of Astragalus species are good candidates for vaccine formulations requiring higher immune response. Consequently, our findings warrant further studies focusing on the in vivo potential of the tested saponins and their mechanism of actions.

\section{Materials and methods}

\subsection{Experimental}

Optical rotations were measured on a standard Bruker program on an Ultra Shield Plus $500 \mathrm{MHz}$ (Bruker) (NMR Unit at the College of Pharmacy, Prince Sattam Bin Abdulaziz University) spectrometer operating at $500 \mathrm{MHz}$ for proton and $125 \mathrm{MHz}$ for carbon. The chemical shift values were represented in $\delta$ (ppm) comparing to the residual solvent peak, and the coupling constants $(J)$ were reported in Hertz $(\mathrm{Hz})$ and MS spectra were measured on a LC/MS High resolution Time of Flight (TOF) Agilent 1200/6530 instrument; CC, silica gel 60 (MERCK); GPC (General Permeation Chromatography, Sephadex LH20). All 2D NMR spectra were obtained in $\mathrm{CDCl}_{3}$ and $\mathrm{CD}_{3} \mathrm{OD}(99.50 \%$, Sigma Aldrich) standard pulse sequences and phase cycling were used for COSY, HSQC and HMBC spectra.

\subsection{Plant material}

The root and stem of $A$. karjaginii were collected from Naghadeh City, Sheykhan Mountain, altitude of $2450 \mathrm{~m}$, West Azerbaijan Province, Iran, in August 2013, and identified by Dr. Ali-Asghar Massoumi (botanist) in Research Institute of Forests and Rangelands. A voucher has been deposited (Tehran 19,537) at the Herbarium of Research and Application Center in Research Institute of Forests and Rangelands, Tehran, Iran.

\subsection{Extraction and isolation}

The root of the plant material $(1000 \mathrm{~g})$ was extracted with $\mathrm{MeOH}$ $(5 \times 6 \mathrm{~L})$ for 5 days under reflux. After filtration, the solvent was removed by rotary evaporation to obtain a dark residue $(101.0 \mathrm{~g})$. Then it was suspended in water $(800 \mathrm{~mL})$, and respectively was partitioned with $n$-hexane $(4 \times 400 \mathrm{~mL}), \quad \mathrm{CH}_{2} \mathrm{Cl}_{2} \quad(4 \times 400 \mathrm{~mL}), \quad$ EtOAc $(4 \times 400 \mathrm{~mL})$ and $n-\mathrm{BuOH}(4 \times 400 \mathrm{~mL})$. The $\mathrm{BuOH}$ extract $(70 \mathrm{~g})$ was subjected to VLC (Lichroprep RP-18, 25-40 $\mu \mathrm{m}, 180 \mathrm{~g}$ ) using reversed-phase silica gel utilizing $\mathrm{MeOH}-\mathrm{H}_{2} \mathrm{O}$ solvent systems employing $\mathrm{H}_{2} \mathrm{O}(1000 \mathrm{~mL}), \mathrm{H}_{2} \mathrm{O}-\mathrm{MeOH}(80: 20,1200 \mathrm{~mL} ; 60: 40,2400 \mathrm{~mL} ; 40: 60$, $3200 \mathrm{~mL} ; 20: 80,1800 \mathrm{~mL})$ and $\mathrm{MeOH}(800 \mathrm{~mL})$ to give 20 main fractions (A to T). Fraction $\mathrm{C}$ was applied to an open column chromatography using normal-phase silica gel $(23 \times 1200 \mathrm{~mm}, 600 \mathrm{~g})$ as stationary phase with the solvent system $\mathrm{CHCl}_{3}-\mathrm{MeOH}-\mathrm{H}_{2} \mathrm{O}$ (90:10:1, $2000 \mathrm{~mL} ; 80: 20: 2,1500 \mathrm{~mL} ; 70: 30: 3,2000 \mathrm{~mL}$ ) resulting to fractions $\mathrm{C} 1-\mathrm{C} 986$. The fractions $\mathrm{C} 600$ to $\mathrm{C} 712(1.0 \mathrm{~g})$ were combined and applied to vacuum liquid chromatography (VLC) using reversed-phase silica gel (Lichroprep RP-18, 25-40 $\mu \mathrm{m}$ ) employing $\mathrm{MeOH}-\mathrm{H}_{2} \mathrm{O}$ solvent system (40:60, $700 \mathrm{~mL} ; 50: 50,1500 \mathrm{~mL} ; 60: 40,1500 \mathrm{~mL} ; 70: 30$, $1000 \mathrm{~mL} ; 80: 20,1000 \mathrm{~mL}$ and $\mathrm{MeOH}, 700 \mathrm{~mL}$ ) to yield $1(15 \mathrm{mg})$ and 3 $(400 \mathrm{mg})$. Fraction $\mathrm{K}(6.0 \mathrm{~g})$ was also applied to an open column chromatography containing normal-phase silica gel $(30 \times 1200 \mathrm{~mm}$, $600 \mathrm{~g}$ ) with the solvent system (90:10:1, $2000 \mathrm{~mL} ; 85: 15: 1.5,2300 \mathrm{~mL}$; 80:20:2, $1000 \mathrm{~mL} ; 75: 25: 2.5,1000 \mathrm{~mL} ; 70: 30: 3,800 \mathrm{~mL} ; 61: 32: 7$, 
$1500 \mathrm{~mL} ; \quad 64: 50: 10, \quad 2000 \mathrm{~mL})$ to provide 3119 subfractions. Subfractions 600 and 894 (56 mg) were combined and applied over reversed-phase material (Lichroprep RP-18, 25-40 $\mu, 35 \mathrm{~g}$ ) eluting with $\mathrm{MeOH}-\mathrm{H}_{2} \mathrm{O}(50: 50,800 \mathrm{~mL} ; 60: 40,500 \mathrm{~mL} ; 70: 30,500 \mathrm{~mL} ; 80: 20$, $900 \mathrm{~mL} ; 90: 10,600 \mathrm{~mL} ; 100: 0,800 \mathrm{~mL})$ yielding $4(9.0 \mathrm{mg})$ and 5 $(14 \mathrm{mg}) . \mathrm{K} 900$ and $\mathrm{K} 1168(250 \mathrm{mg})$ were combined and eluted with $\mathrm{CHCl}_{3}-\mathrm{MeOH}-\mathrm{H}_{2} \mathrm{O}$ (85:15:1.5, $600 \mathrm{~mL} ; 80: 20: 2,500 \mathrm{~mL} ; 75: 25: 2.5$, $1000 \mathrm{~mL} ; 70: 30: 3,600 \mathrm{~mL}$ ) over an open column chromatography including normal-phase silica gel $(22 \times 900 \mathrm{~mm}, 200 \mathrm{~g})$ to give subfractions KA1-KA589, from which subfractions KA200-KA332 (54 mg) were combined and subjected to open column chromatography filled with reversed-phase material (Lichroprep RP-18, 25-40 $\mu \mathrm{m}, 38 \mathrm{~g}$ ) eluting with $\mathrm{MeOH}-\mathrm{H}_{2} \mathrm{O}$ (50:50, $300 \mathrm{~mL} ; 60: 40,300 \mathrm{~mL} ; 70: 30$, $300 \mathrm{~mL} ; 80: 20,250 \mathrm{~mL} ; 90: 10,100 \mathrm{~mL} ; 100: 0,100 \mathrm{~mL}$ ) to give compound $6(10 \mathrm{mg})$ and 7 (38 mg). Fractions K1456-K1561 were combined and further separated over normal phase silica gel $(20 \times 250 \mathrm{~mm}, 60.6 \mathrm{~g})$ using a step-gradient of EtOAc-MeOH-H $\mathrm{H}_{2} \mathrm{O}$ $(100: 10: 5, \quad 300 \mathrm{~mL} ; 100: 15: 7.5, \quad 400 \mathrm{~mL} ; 100: 17.5: 13.5, \quad 350 \mathrm{~mL}$; $100: 20: 15,200 \mathrm{~mL} ; 100: 25: 20,300 \mathrm{~mL}$ ) to give 489 subfractions (KB1KB489). Subfractions KB161-KB178 (35 mg) were combined and chromatographed over normal phase silica gel $(22 \times 390 \mathrm{~mm}, 90 \mathrm{~g})$ employing with $\mathrm{CHCl}_{3}-\mathrm{MeOH}-\mathrm{H}_{2} \mathrm{O}$ (90:10:1, $200 \mathrm{~mL} ; 80: 20: 1,400 \mathrm{~mL}$; 80:20:2, $150 \mathrm{~mL} ; 70: 30: 3,200 \mathrm{~mL} ; 61: 32: 7,100 \mathrm{~mL})$ mixtures and methanol to afford compounds $8(10 \mathrm{mg})$ and $9(9.3 \mathrm{mg})$. Subfractions KB200-KB310 (55 mg) were combined and subjected to column chromatography containing reversed-phase material (Lichroprep RP-18, $25-40 \mu \mathrm{m}, 88 \mathrm{~g}$ ) and eluted with isocratic $\mathrm{MeOH}-\mathrm{H}_{2} \mathrm{O}$ mobile phase system $(60: 40,300 \mathrm{~mL} ; 40: 60,500 \mathrm{~mL} ; 20: 80,700 \mathrm{~mL})$ to give a mixture including two compounds ( $45 \mathrm{mg}$ ). As the open column chromatography silica gel and RP-18 trials failed to separate these two metabolites from the mixture due to their similar polarities, the mixture was acetylated using acetic anhydride and pyridine. After acetylation, the mixture was applied to column chromatography by using normal-phase silica gel $(20 \times 260 \mathrm{~mm}, 22.2 \mathrm{~g})$ eluting with $\mathrm{CHCl}_{3}$-acetone (80:20, $300 \mathrm{~mL} ; 70: 30,300 \mathrm{~mL} ; 60: 40,200 \mathrm{~mL} ; 50: 50,200 \mathrm{~mL} ; 40: 60,100 \mathrm{~mL}$ ) to yield compound $\mathbf{2 a}(25 \mathrm{mg})$. Then, compound $2 \mathbf{a}(5 \mathrm{mg})$ was deacetylated to obtain compound $2(2.5 \mathrm{mg})$. Before the acetylation reaction took place, the mixture was analyzed by ${ }^{1} \mathrm{H}$ NMR to make sure that no acetyl group was present in the structure of the starting compounds. Fractions O2687-O2900 (4.0 g) were mixed and subjected to an open column chromatography using silica gel $(30 \times 1200 \mathrm{~mm}, 500 \mathrm{~g})$ as stationary phase using (90:10:1, $1500 \mathrm{~mL} ; 80: 20: 2,2500 \mathrm{~mL} ; 70: 30: 3$, $1000 \mathrm{~mL}$ ) concluding 1432 subfractions. Subfractions O200-O453 (226 mg) were combined and fractionated over reversed-phase material (Lichroprep RP-18, 25-40 $\mu \mathrm{m}, 106 \mathrm{~g}$ ) using reversed-phase silica processing with $\mathrm{MeOH}-\mathrm{H}_{2} \mathrm{O}$ (50:50, $1000 \mathrm{~mL} ; 40: 60,3000 \mathrm{~mL} ; 30: 70$, $1000 \mathrm{~mL} ; 20: 80,2000 \mathrm{~mL}$ and $\mathrm{MeOH}, 800 \mathrm{~mL}$ ) mixture to afford compounds $12(9.4 \mathrm{mg})$ and $13(11 \mathrm{mg})$. Subfractions O600-0836 (400 mg) were combined and separated over normal phase silica gel $(23 \times 450 \mathrm{~mm}, 60.6 \mathrm{~g})$ using a step-gradient of EtOAc-MeOH- $\mathrm{H}_{2} \mathrm{O}$ $(100: 10: 5, \quad 400 \mathrm{~mL} ; 100: 15: 7.5, \quad 450 \mathrm{~mL} ; 100: 17.5: 13.5, \quad 500 \mathrm{~mL}$; $100: 20: 15,200 \mathrm{~mL} ; 100: 25: 20,250 \mathrm{~mL}$ ) to give 689 subfractions (OA1QA689). After mixing subfractions OA432-OA561 (450 mg), the mixture was separated utilizing $\mathrm{CHCl}_{3}-\mathrm{MeOH}-\mathrm{H}_{2} \mathrm{O}(80: 20: 2,1000 \mathrm{~mL}$; 70:30:3, $900 \mathrm{~mL} ; 61: 32: 7,700 \mathrm{~mL}$ ) over an open column chromatography filled with normal-phase silica gel $(23 \times 360 \mathrm{~mm}, 200 \mathrm{~g})$ to obtain compound 11 (18 mg) and 10 (10 mg). Subfractions O1002$01231(700 \mathrm{mg}$ ) were combined and subjected to an open column chromatography using $\mathrm{CHCl}_{3}-\mathrm{MeOH}-\mathrm{H}_{2} \mathrm{O}$ (95:5:0.5, $900 \mathrm{~mL}$; 90:10:1, $500 \mathrm{~mL} ; 85: 15: 1.5,800 \mathrm{~mL} ; 70: 30: 3,1200 \mathrm{~mL}$ ) to acquire 781 fractions (OB1-OB781), from which fractions OB456-OB741 (200 mg) were combined and applied to a column chromatography including reversedphase material (Lichroprep RP-18, 25-40 $\mu, 75 \mathrm{~g}$ ) using $\mathrm{MeOH}-\mathrm{H}_{2} \mathrm{O}$ (50:50, $400 \mathrm{~mL} ; 40: 60,800 \mathrm{~mL} ; 30: 70,400 \mathrm{~mL} ; 20: 80,500 \mathrm{~mL}$ and $\mathrm{MeOH}, 600 \mathrm{~mL})$ to afford compounds $14(8.5 \mathrm{mg})$ and $15(12 \mathrm{mg})$.

\subsection{Acid hydrolysis}

Fraction Q (1.0 g), a crude saponin extract of $A$. karjaginii, was heated at $60^{\circ} \mathrm{C}$ with $1: 10.5 \mathrm{~N} \mathrm{HCl}$-dioxane $(3 \mathrm{~mL})$ for $2 \mathrm{~h}$. After cooling, the solution was concentrated in rotary. The solution was partitioned with EtOAc and the $\mathrm{H}_{2} \mathrm{O}$ part was separated and neutralized with $0.5 \mathrm{M}$ $\mathrm{NaOH}$. After obtaining the hydrolyzed mixture, three monosaccharides were purified utilizing normal-phase silica gel as stationary phase $(60 \mathrm{~g})$ eluting with $\mathrm{CHCl}_{3}-\mathrm{MeOH}-\mathrm{H}_{2} \mathrm{O}$ solvent system (95:5:0.5, $80: 20: 1,80: 20: 2 ; 70: 30: 3 ; 61: 32: 7)$. After separation, the obtained sugar was identified by comparison with authentic samples tested with TLC using $\mathrm{CHCl}_{3}-\mathrm{MeOH}-\mathrm{H}_{2} \mathrm{O}$ (60:40:10) system. The optical rotation of purified sugar was measured to afford D-xylose $\left([\alpha]_{\mathrm{D}}^{20}+22.0, c 0.1\right.$, $\mathrm{H}_{2} \mathrm{O}$ ).

\subsection{In vitro bioactivity assays}

\subsubsection{Immunomodulatory assay: measurement of the effects on cytokine production}

Heparinized peripheral human whole obtained from healthy volunteers were stimulated with 50 ng PMA (Sigma, St. Lois, MO, U.S.A.) plus $400 \mathrm{ng}$ ionomycin (Sigma, St. Lois, MO, U.S.A.) for IL-2, IFN- $\gamma$ and IL-17A and incubated in the presence of test samples or reference compound QS-21 for $48 \mathrm{~h}$. The previously cultured supernatants were collected and the concentration of the cytokines, which were produced by macrophages or lymphocytes, was measured utilizing a commercially available enzyme-linked immunosorbent assay (ELISA) (Vienne, Austria). Manufacturer's recommendations were the source for performing the assays. The average absorbance readings of the samples were then compared with the concentrations of the standard curve. The concentration of each cytokine in each sample was calculated. The results of tested cytokines were given as picograms per milliliter. The minimum detection limits were $9.1 \mathrm{pg} / \mathrm{mL}, 0.99 \mathrm{pg} / \mathrm{mL}$, and $0.5 \mathrm{pg} / \mathrm{mL}$ for IL-2, IFN- $\gamma$ and IL-17A, respectively. Diluted supernatants were used for all assays and each assay was performed in triplicate.

\subsubsection{Peripheral whole-blood cultures}

The RPMI-1640 medium suspended human whole blood (containing $20 \mathrm{U} / \mathrm{mL}$ heparine) was supplemented with $\% 10 \mathrm{FBS}, 100 \mathrm{U} / \mathrm{mL}$ penicillin and $100 \mathrm{mg} / \mathrm{mL}$ streptomycin in a $1: 10$ ratio. PMA $(50 \mathrm{ng} / \mathrm{mL})$ plus ionomycin $(400 \mathrm{ng} / \mathrm{mL})$ were added to the whole blood for previous stimulation of immune system cells. DMSO was used as stock solution to dissolve the samples at concentration of $5 \mathrm{mg} / \mathrm{mL}$. Besides, DMSO was used as negative control. An amount of $1 \mathrm{~mL}$ of the heparinized blood stimulated by PMA ( $50 \mathrm{ng} / \mathrm{mL}$ ) plus ionomycin ( $400 \mathrm{ng}$ / $\mathrm{mL}$ ) was transferred into each well of 24-well plate and incubated at $37{ }^{\circ} \mathrm{C}$ for 48 in the absence or presence of 3 or $6 \mu \mathrm{g} / \mathrm{mL}$ concentrations of samples or QS-21 and AST VII as positive controls. The diluted culture supernatants were then mixed with sample diluent at 1:2 ratio. Furthermore, they were assayed using the specific ELISA method for IL2 , IFN- $\gamma$ and IL-17A $[26,58,59]$. The protocol was approved by the Human Ethics Committee of Ege University, and all of the used procedures conformed to the protocol was approved by the Human Ethics Committee of Ege University, and all of the used procedures conformed to the declaration of Helsinki. All of the tested were carried out under approval of the mentioned organization (approval number 15-11/19).

\subsubsection{Hemolytic activity assay}

The potential for hemolysis of the molecules was calculated according to Nalbantsoy et al. (2011) with some modifications [26]. Red blood cells were collected with BD Vacutainer TM (NH 143 I. U., Belliver Industrial Estate, Plymouth, UK) from human healthy volunteers. Blood $(7 \mathrm{~mL})$ was washed three times using sterile saline solution $(0.89 \%, w / v \mathrm{NaCl}$, pyrogen free). Moreover, it was centrifuged at $2000 \times \mathrm{g}$ for $5 \mathrm{~min}$. The pellet diluted to $0.5 \%$ with saline solution was prepared to obtain the final cell suspension. The cell suspension 
(0.01 mL) was mixed in $\mathrm{U}$ button 96 -well microplate with $0.05 \mathrm{~mL}$ diluents containing $2.5,12.5,25,50,125,250,500$ and $5000 \mu \mathrm{g} / \mathrm{mL}$ concentrations of molecules in saline solutions. The blends were incubated for $30 \mathrm{~min}$ at $37^{\circ} \mathrm{C}$ and then were centrifuged at $800 \times \mathrm{g}$ for $10 \mathrm{~min}$. The free hemoglobin belonging to each supernatant was measured using spectrophotometry at $412 \mathrm{~nm}$. Minimal and maximal hemolytic controls were saline solution and distilled water respectively. For measurement of the final hemolytic percent, the hemolytic percent which was developed by the saline control was subtracted from all groups. Each experiment was tested as triplicates at each concentration.

\section{Statistical analysis}

The obtained data were displayed as mean \pm standard deviation (S.D.) and were examined for their statistical significance of difference with Student $t$-test, One-way ANOVA and the post hoc test dunnet and Tamhane's (depends on both normality and homogeneity of the absorbance values) utilizing SPSS 16.0. $P$-values $<0.05,0.01$ and 0.001 , were considered significant statistically.

$6 \alpha, 16 \beta, 24(S), 25$-tetrahydroxycycloartane-3-one (1): Amorphous white solid; $\mathrm{C}_{30} \mathrm{H}_{50} \mathrm{O}_{5} ;[\alpha]_{\mathrm{D}}^{24}-1.2(c 0.1 \mathrm{MeOH}) ; \mathrm{IR} \nu_{\max }^{\mathrm{KBr}} \mathrm{cm}^{-1}: 3430$ (> OH), $2920(>\mathrm{CH}), 1740(\mathrm{C}=\mathrm{O})$; for ${ }^{1} \mathrm{H}$ and ${ }^{13} \mathrm{C} \mathrm{NMR}\left(\mathrm{CDCl}_{3}\right.$, $500 \mathrm{MHz}$ ) data see Tables 1 and 2; HRESIMS $m / z 513.3563[\mathrm{M}+\mathrm{Na}]^{+}$ (calcd. for $\mathrm{C}_{30} \mathrm{H}_{50} \mathrm{O}_{5} \mathrm{Na}, 513.3560$ ) (positive mode).

6-O- $\beta$-D-xylopyranosyl-3 $\beta, 6 \alpha, 16 \beta, 24(S), 25$-pentahydroxycycloartane (2): Amorphous white solid; $\mathrm{C}_{35} \mathrm{H}_{60} \mathrm{O}_{9}$; $[\alpha]_{\mathrm{D}}^{24}+1.6$ (c 0.1 MeOH); IR $\nu_{\max }^{\mathrm{KBr}} \mathrm{cm}^{-1}: 3420$ (> OH), 2900 (> CH); for ${ }^{1} \mathrm{H}$ and ${ }^{13} \mathrm{C}$ NMR $\left(\mathrm{CD}_{3} \mathrm{OD}\right.$, $500 \mathrm{MHz}$ ) data see Tables 1 and 2; HRESIMS $m / z 647.4147[\mathrm{M}+\mathrm{Na}]^{+}$ (calcd. For $\mathrm{C}_{35} \mathrm{H}_{60} \mathrm{O}_{9} \mathrm{Na}, 647.4145$ ) (positive mode).

6-O- $\beta$-D-xylopyranosyl-3 $\beta, 6 \alpha, 16 \beta, 24(S), 25-p e n t a h y d r o x y c y c l o a r t a n e$ hexaaacetate (2a): Amorphous white solid; $\mathrm{C}_{35} \mathrm{H}_{60} \mathrm{O}_{9} ;[\alpha]_{\mathrm{D}}^{23}+6.0(c 0.2$ $\mathrm{MeOH}), \mathrm{IR} \nu_{\max }^{\mathrm{KBr}} \mathrm{cm}^{-1}: 3450(>\mathrm{OH}), 1246(>\mathrm{CH}), 1733(\mathrm{C}=\mathrm{O})$; for ${ }^{1} \mathrm{H}$ and ${ }^{13} \mathrm{C}$ NMR $\left(\mathrm{CDCl}_{3}, 500 \mathrm{MHz}\right)$ data see Tables 1 and 2.

\section{Conflict of interest declaration}

The authors whose names are listed immediately below certify that they have NO affiliations with or involvement in any organization or entity with any financial interest (such as honoraria; educational grants; participation in speakers' bureaus; membership, employment, consultancies, stock ownership, or other equity interest; and expert testimony or patent-licensing arrangements), or non-financial interest (such as personal or professional relationships, affiliations, knowledge or beliefs) in the subject matter or materials discussed in this manuscript.

\section{Acknowledgements}

The authors gratefully acknowledge to the financial support of Ege University BAP Research Foundation (15-FBE-001) for the financial support and thank Prof. Dr. Ali Asghar Maassoumi for the identification of the plant material, and special thanks to NMR operator of Prince Sattam bin Abdulaziz University titled Anzarulhaque Anwarulhaque.

\section{Appendix A. Supplementary data}

Supplementary data to this article can be found online at http://dx. doi.org/10.1016/j.fitote.2017.08.008.

\section{References}

[1] M. Ranjbar, R. Karamian, Astragalus sect. Astragalus (Fabaceae) in Iran, complementary notes with a key to the species, Nor. J. Bot. 2 (2002) 177-181.

[2] A.A. Massoumi, Old World Checklist of Astragalus, fourth ed., Research Institute of Forests and Rangeland, Iran, 1998.

[3] E. Bedir, İ. Çalıs, O. Zerbe, O. Sticher, Cyclocephaloside I: a novel cycloartane-type glycoside from Astragalus microcephalus, J. Nat. Prod. 61 (1998) 503-505.
[4] E. Bedir, İ. Çalis, R. Aquino, S. Piacente, C. Pizza, H. Trojanoside, A cycloartanetype glycoside from the arial parts of Astragalus trojanus, Phytochemistry 51 (1999) 1017-1020.

[5] E. Bedir, İ. Çalıs, R. Aquino, S. Piacente, C. Pizza, Secondary metabolites from the roots of Astragalus trojanus, J. Nat. Prod. 62 (1999) 563-568.

[6] İ. Çaliş, A.A. Dönmez, A. Perrone, C. Pizza, S. Piacente, Cycloartane glycosides from Astragalus campylosema Boiss. ssp. Campylosema, Phytochemistry 69 (2008) 2634-2638.

[7] D. Gülcemal, M. Masullo, E. Bedir, M. Festa, T. Karayıldırım, Ö. Alankuş Çalışkan, S. Piacente, Triterpene glycosides from Astragalus angustifolius, Planta Med. 78 (2012) 720-729.

[8] D. Gülcemal, M. Masullo, A. Napolitano, T. Karayıldırım, E. Bedir, Alankuş-Calışkan $\mathrm{O}$, Piacente S, Oleanane glycosides from Astragalus tauricolus: isolation and structural elucidation based on a preliminary liquid chromatography-electrospray ionization tandem mass spectrometry profiling, Phytochemistry 86 (2013) 184-194.

[9] I. Horo, E. Bedir, A. Perrone, F. Özgökce, S. Piacente, Ö. Alankuş-Calışkan, Triterpene glycosides from Astragalus icmadophilus, Phytochemistry 71 (2010) 956-973.

[10] I. Horo, E. Bedir, M. Masullo, S. Piacente, F. Özgökce, Ö. Alankuş-Calışkan, Saponins from Astragalus hareftae (NAB.) SIRJ, Phytochemistry 84 (2012) 147-153.

[11] T. Savran, D. Gülcemal, M. Masullo, T. Karayıldırım, E. Polat, S. Piacente, Ö. Alankuş-Çalışkan, Cycloartane glycosides from Astragalus erinaceus, Rec. Nat. Prod. 6 (2012) 230-236.

[12] N. Denizli, I. Horo, D. Gulcemal, M. Masullo, M. Festa, A. Capasso, O. Koz, S. Piacente, O. Alankus-Caliskan, Cycloartane glycosides from Astragalus plumosus var. krugianus and evaluation of their antioxidant potential, Fitoterapia 92 (2014) 211-218.

[13] R. Un, İ. Horo, M. Masullo, A. Falco, S.G. Senol, S. Piacente, Ö. Alankus-Caliskan, Cycloartane and oleanane-type glycosides from Astragalus pennatulus, Fitoterapia 109 (2016) 254-260.

[14] S. Behboudi, B. Morein, M.C. Villacres-Eriksson, Quillaja saponin formulations that stimulate proinflammatory cytokines elicit a potent acquired cell-mediated immunity, Scand. J. Immunol. 50 (1999) 371-377.

[15] J.L. Rios, P.G. Waterman, A review of the pharmacology and toxicology of Astragalus, Phytother. Res. 11 (1997) 411-418.

[16] E. Bedir, N. Pugh, İ. Çalış, D.S. Pasco, I.A. Khan, Immunostimulatory effects of cycloartane-type triterpene glycosides from Astragalus species, Biol. Pharm. Bull. 23 (2000) 834-837.

[17] W.C. Cho, K.N. Leung, In vitro and in vivo immunomodulating and immunorestorative effects of Astragalus membranaceus, J. Ethnopharmacol. 113 (2007) $132-141$.

[18] Z.I. Rajput, S. Hu, C. Xiao, A.G. Arijo, Review: adjuvant effects of saponins on animal immune, J Zhejiang Univ Sci B 8 (2007) 153-161.

[19] I.N. Krasteva, R.A. Toshkova, S.D. Nikolov, Protective effect of Astragalus corniculatus saponins against myeloid graffi tumour in hamsters, Phytother. Res. 183 (2004) 255-257.

[20] J.H. Kim, M.H. Kim, G. Yang, Y. Huh, S.H. Kim, W.M. Yang, Effects of topical application of Astragalus membranaceus on allergic dermatitis, Immunopharmacol. Immunotoxicol. 35 (2013) 151-156.

[21] V.R. Netala, S.B. Ghosh, P. Bobbu, D. Anitha, V. Tartte, Triterpenoid saponins: a review on biosynthesis, applications and mechanism of their action, Int J Pharm Pharm Sci 7 (2015) 24-28.

[22] M.A. Lacaille-Dubois, H. Wagner, A review of the biological and pharmacological activities of saponins, Phytomedicine 2 (1996) 363-386.

[23] G. Francis, Z. Kerem, H.P.S. Makkar, K. Becker, The biological action of saponins in animal systems: a review, Br. J. Nutr. 88 (2002) 587-605.

[24] F. Hashem Dabaghian, M. Kamalinejad, A. Shojaei, M. Abdollahi Fard, Presenting anti-diabetic plants in Iranian traditional medicine, J. Diabetes. Endocrinol. 3 (2012) 70-76.

[25] E. Yeșilada, E. Bedir, İ. Çalıș, Y. Takaishi, Y. Ohmoto, Effects of triterpene saponins from Astragalus species on in vitro cytokine release, J. Ethnopharmacol. 96 (2005) 71-77.

[26] A. Nalbantsoy, T. Nesil, S. Erden, İ. Calıș, E. Bedir, Adjuvant effects of Astragalus saponins Macrophyllosaponin B and Astragaloside VII, J. Ethnopharmacol. 134 (2011) 897-903.

[27] E. Bedir, İ. Çalis, R. Aquino, S. Piacente, C pizza, Cycloartane triterpene glycosides from the roots of Astragalus brachypterus and Astragalus microcephalus, J. Nat. Prod. 61 (1998) 1469-1472.

[28] M.I. Isaev, B.A. Imomnazarov, Y.M. Fadeev, P.A. Kintya, Triterpene glycosides of Astragalus and their genins. XLII. Cycloartanes of Astragalus tragacantha, Khim. Prir. Soedin. 3 (1992) 360-367.

[29] I. Kitagawa, H.K. Wang, A. Takagi, M. Fuchida, I. Miura, M. Yoshikawa, Saponin and Sapogenol.XXXVI. Chemical constituents of astragali radix the Root of Astragalus membranaceus BUNGE. (1). Cycloastragenol, the 9, 19-Cycloanostanetype aglycone of Astragalosides, and the artifact aglycone astragenol, Chem. Pharm. Bull. 31 (1983) 689-697.

[30] I. Kitagawa, H.K. Wang, M. Saito, M. Yoshikawa, Saponin and sapogenol. XXXVII. Chemical constituents of astragali radix, the root of Astragalus membranaceus Bunge. (4). Astragaloside VII and VIII, Chem. Pharm. Bull. 31 (1983) 716-722.

[31] M.D. Alaniya, N.S.H. Kavtaradze, R. Faure, L. Debrauwer, Cycloascauloside B from Astragalus caucasicus, Chem. Nat. Compd. 44 (2008) 324-326.

[32] L. Gan, X. Han, Y. Chen, The chemical investigation of Astragalus sieversianus Pall. Part 2. Astrasieversianins IX, XI and XV, cycloartane derived saponins from Astragalus sieversianus, Phytochemistry 25 (1986) 1437-1441.

[33] D. Gülcemal, Ö. Alankuş-Calışkan, A. Perrone, F. Özgökce, S. Piacente, E. Bedir, Cycloartane glycosides from Astragalus aureus, Phytochemistry 72 (2011) 761-768. 
[34] Y.M. Fadeev, M.I.I. Saev, Y.A. Akimov, P.K. Kintya, M.B. Gorovits, N.K. Abubakirov, Triterpene glycosides of Astragalus and their genins. XXV. Cyclocanthoside D from Astragalus tragacantha, Chem. Nat. Compd. 24 (1988) 62-65.

[35] L. Borish, L. Rosenwasser, Update on cytokines, J. Allergy Clin. Immunol. 97 (1996) 719-730.

[36] K.A. Smith, Interleukin-2: inception, impact, and implications, Science 240 (1988) 1169-1176.

[37] F.M. Brennan, M. Feldmann, Cytokines in autoimmunity, Curr. Opin. Immunol. 8 (1996) 872-877.

[38] J.P. Lodolce, D.L. Boone, S. Chai, R.E. Swain, T. Dassopoulos, S. Trettin, A. Ma, IL15 receptor maintains lymphoid homeostasis by supporting lymphocyte homing and proliferation, Immunity 9 (1998) 669-676.

[39] S. Romagnani, Induction of TH1 and TH2 responses: a key role for the 'natural' immune response? Immunol. Today 13 (1992) 379-381.

[40] L. Xiaoxia, Q. Lu, D. Yongzhe, H. Lifeng, L. Erwei, F.Z.Y. Shiming, T. Wang, A review of recent research progress on the Astragalus genus, Molecules 19 (2014) $18850-18880$.

[41] I. Podolak, A. Galanty, D. Sobolewska, Saponins as cytotoxic agents: a review, Phytochem. Rev. 9 (2010) 425-474.

[42] E. Rouvier, M. Luciani, M. Mattéi, F. Denizot, P. Golstein, CTLA-8, cloned from an activated T cell, bearing AU-rich messenger RNA instability sequences, and homologous to a herpesvirus saimiri gene, J. Immunol. 150 (1993) 5445-5456.

[43] S. Aggarwal, A.L. Gurney, IL-17: prototype member of an emerging cytokine family, J. Leukoc. Biol. 71 (2002) 1-8.

[44] L. Zhou, Y.L. Shi, K. Li, I. Hamzavi, T.W. Gao, R.H. Huggins, H.W. Lim, Q.S. Mi, Increased circulating Th17 cells and elevated serum levels of TGF-beta and IL-21 are correlated with human non-segmental vitiligo development, Pigment Cell Melanoma Res. 28 (2015) 324-329.

[45] S. Gillis, D. Williams, Cytokine therapy: lessons learned and future challenges, Curr. Opin. Immunol. 10 (1998) 501-503.

[46] K. Oda, H. Matsuda, T. Murakami, S. Katayama, T. Ohgitani, M. Yoshikawa, Relationship between adjuvant activity and amphipathic structure of soya saponins, Vaccine 21 (2003) 2145-2151.

[47] A. Pandey, M. Rizvi, B. Ali Shah, S. Bani, Anti-arthritogenic effect of Saponin-1 by alteration of Th1/Th2 cytokine paradigm in arthritic mice, Cytokine 79 (2016) 103-113.
[48] Y. Hu, A. Mao, Y. Tan, Y. Zhao, K. He, Role of 5 Saponins in secretion of cytokines by PRRSV-induced endothelial cells, Drug. Res. 66 (2016) 357-362.

[49] Z.G. Yang, H.X. Suna, W.H. Fang, Hemolytic activities and adjuvant effect of Astragalus membranaceus saponins (AMS) on the immune responses to ovalbumin in mice, Vaccine 23 (2005) 5196-5203.

[50] A. Nalbantsoy, T. Nesil, O. Yilmaz-Dilsiz, G. Aksu, S. Khan, E. Bedir, Evaluation of the immunomodulatory properties in mice and in vitro anti-inflammatory activity of cycloartane type saponins from Astragalus species, J. Ethnopharmacol. 139 (2012) 574-581.

[51] X.O. Yang, S.H. Chang, H. Park, R. Nurieva, B. Shah, L. Acero, Y.H. Wang, K.S. Schluns, R.R. Broaddus, Z. Zhu, C. Dong, Regulation of inflammatory responses by IL-17F, J. Exp. Med. 205 (2008) 1063-1075.

[52] B. Ronnberg, M. Fekadu, S. Behboudi, L. Kenne, B. Morein, Effects of carbohydrate modification of Quillaja Saponaria Molina QH-B fraction on adjuvant activity, cholesterolbinding capacity and toxicity, Vaccine 15 (1997) 1820-1826.

[53] S.C. Bang, J.H. Lee, G.Y. Song, D.H. Kim, M.Y. Yoon, B.Z. Ahn, Antitumor activity of Pulsatilla koreana saponins and their structure-activity relationship, Chem. Pharm. Bull. 53 (2005) 1451-1454.

[54] S.C. Bang, H.H. Seo, H.Y. Yun, S.H. Jung, Facile synthesis of trisaccharide moiety corresponding to antitumor activity in triterpenoid saponins isolated from Pulsatilla roots, Chem. Pharm. Bull. 55 (2007) 1734-1739.

[55] Y. Xie, Y.P. Ye, H. Sun, D. Li, Contribution of the glycidic moieties to the hemolytic and adjuvant activity of platycodigenin-type saponins from the root of Platycodon grandiflorum, Vaccine 26 (2008) 3452-3460.

[56] Y. Sun, H. Tong, M. Li, Y. Li, S. Guand, J. Liu, Immunological adjuvant effect of Japanese ginseng saponins (JGS) on specific antibody and cellular response to ovalbumin and its hemolytic activities, Vaccine 26 (2008) 5911-5917.

[57] R. Bissinger, P. Modicano, K. Alzoubi, S. Honisch, C. Faggio, M. Abed, F. Lang, Effect of saponin on erythrocytes, Int. J. Hematol. 100 (2014) 51-59.

[58] A. Lenarczyk, J. Helsloot, K. Farmer, L. Peters, A. Sturgess, B. Kirkham, Antigen induced IL-17A response in the peripheral blood mononuclear cells (PBMC) of healthy controls, Clin. Exp. Immunol. 122 (2000) 4-18.

[59] E. Yeşilada, O. Ustün, E. Sezik, Y. Takaishi, Y. Ono, G. Honda, Inhibitory effects of Turkish folk remedies on inflammatory cytokines: interleukin-1alpha, interleukin1beta and tumor necrosis factor alpha, J. Ethnopharmacol. 58 (1997) 59-73. 